\title{
Mineral Nutrients and Plant-Fungal Interaction in Cocoa Trees (Theobroma cacao L.)
}

\author{
Hélio R. Sousa Filho, ${ }^{a}$ Raildo M. de Jesus, ${ }^{b}$ Marcos A. Bezerra, ${ }^{\circledR} *, c$ \\ Vinnícius H. C. da Silva, ${ }^{b}$ André L. S. da Silva Jr., Juscelia P. S. Alves, ${ }^{c}$ \\ Gregório M. Santana ${ }^{b}$ and José O. de Souza Jr. ${ }^{d}$
}

\author{
aPrograma de Pós-Graduação em Desenvolvimento e Meio Ambiente, \\ Universidade Estadual de Santa Cruz, Rodovia Jorge Amado, km 16, 45662-900 Ilhéus-BA, Brazil \\ ${ }^{b}$ Programa de Pós-Graduação em Química, Universidade Estadual de Santa Cruz, \\ Rodovia Jorge Amado, km 16, 45662-900 Ilhéus-BA, Brazil \\ ${ }^{c}$ Departamento de Ciências e Tecnologias, Universidade Estadual do Sudoeste da Bahia, \\ Av. José Moreira Sobrinho, s/n, 45206-191 Jequié-BA, Brazil \\ ${ }^{d}$ Departamento de Ciências Agrárias e Ambientais, Universidade Estadual de Santa Cruz, \\ Rodovia Jorge Amado, km 16, 45662-900 Ilhéus-BA, Brazil
}

\begin{abstract}
An infection of the fungus Moniliophthora perniciosa in cocoa trees reduces productivity of the plant. In this study, the concentrations of mineral nutrients in healthy leaves and in leaves of vegetative broom of the cocoa plant were determined, and the relationship between the disease and the nutritional composition of the leaves was assessed. The samples were analyzed using the wet digestion method and the concentrations were determined by inductively coupled plasma optical emission spectrometry and the Kjeldahl method. Results indicate that leaves of vegetative broom have lower concentrations of $\mathrm{Ca}, \mathrm{Mg}, \mathrm{S}, \mathrm{Fe}, \mathrm{Mn}$, and $\mathrm{Ni}$ than healthy leaves. Concentrations of $\mathrm{P}$ and $\mathrm{Cu}$ were lower in healthy leaves and higher in leaves of vegetative broom. In contrast, concentrations of $\mathrm{K}, \mathrm{N}$, and $\mathrm{Zn}$ were the same for both types of leaves. In short, plant-fungal interaction was reflected in the nutritional composition of the leaves, demonstrated by the differences in nutrient concentrations between healthy and infected leaf tissue.
\end{abstract}

Keywords: cocoa tree, Moniliophthora perniciosa, leaf analysis, PCA, ICP OES

\section{Introduction}

Cocoa is a global commodity and its production contributes to the preservation of forest remnants and generates income for millions of producers. More than $80 \%$ of the world's cocoa production originates from small properties; however, this production has been threatened by pests or diseases that reduce yields and affect supply as well as the quality of the beans. ${ }^{1,2}$

In the last decade, there has been a deficit in cocoa supply, while global demand has continued to grow. ${ }^{3}$ In the $20^{\text {th }}$ century, Brazil was one of the leading producers of cocoa, but the emergence of witch's broom disease, caused by the fungus Moniliophthora perniciosa, initiated a crisis in Brazilian production. Consequently, the country fell

*e-mail: mbezerra@uesb.edu.br to sixth position worldwide and even imported cocoa for some years following the crisis. ${ }^{4}$ In the state of Bahia, one of the largest cocoa-producing states in Brazil, the disease initially struck in 1989 and negatively affected productivity of crops, leading to a $50 \%$ drop in production. ${ }^{5}$ This drop in production caused an increase in rural unemployment and a reduction in municipal revenues and urban activities related to cocoa, among other implications. ${ }^{6-8}$

M. perniciosa is a pathogen that invades plant tissues to feed and reproduce. Access to the host occurs in meristematic tissue, via wounds, stomata, and other penetration sites. ${ }^{9}$ This fungus has a hemibiotrophic life cycle, that is, it occurs in two stages, the first biotrophic and the second necrotrophic. Moreover, the fungus can colonize living tissue and remain in biotrophic form from one to three months. ${ }^{10}$ This stage comprises the formation of monokaryotic mycelium in the apoplast, resulting in 
hypertrophy and hyperplasia of the tissues, emergence of auxiliary sprouts, and loss of apical dominance, which are classic symptoms of vegetative brooms or green brooms. ${ }^{10,11}$ The necrotrophic stage consists of the diffusion of dikaryotic mycelium into the intracellular environment, causing necrosis and death of the tissue and the formation of dry brooms. ${ }^{10,12}$

Studies $^{13-16}$ on the interaction of M. perniciosa and hosts have been conducted in recent decades with different approaches, such as life cycle, genomics, proteomics, and infection process. However, some works ${ }^{2,10}$ report that the virulence strategies of fungal parasites have not been fully elucidated given their greater complexity in comparison to bacteria, which have clearer virulence strategies. Therefore, studies ${ }^{17}$ that associate plant phytopathology and nutrition can shed light on plant-fungal interactions since fungal parasite depends on plant nutrients to ensure its growth and development through one-way nutrient transfer from plant to fungus.

With regard to studies on nutrients during plantfungal interaction, one study ${ }^{18}$ using analysis of the leaf tissue of cupuaçu (Theobroma grandiflorum), during the development of witch's broom compared the concentration of some micronutrients in healthy and infected tissue and revealed differences in nutrient concentration between these tissues. Another study, ${ }^{19}$ with cocoa shoots infected with M. perniciosa, showed an initial increase in carbohydrate concentrations in the host apoplast, suggesting the fungus obtains nutrients and avoids plant defenses without premature tissue death. A third study ${ }^{20}$ revealed a correlation between the life cycle of M. perniciosa and the nutritional environment in which it is hosted since nutrient limitations caused autolysis in the fungus as a strategy to recycle fundamental chemical elements for its survival.

Thus, in view of the above, the aim of this study was to determine the concentrations of mineral nutrients in healthy leaves and leaves of vegetative broom in cocoa trees and assess the relationship between the disease and leaf nutrient content.

\section{Experimental}

\section{Study area and sample collection}

The study area is located in the municipality of Ibirapitanga, a cocoa-producing region in the state of Bahia, Brazil. The healthy leaves and leaves of vegetative broom of Theobroma cacao $\mathrm{L}$. were collected on two farms, coded as area $\mathrm{V}$ and area $\mathrm{A}$. On each farm, samples were collected in two cocoa plantations, named site $\mathrm{T}$ and site $\mathrm{B}$, with higher and lower slope in the landscape, respectively, totaling four collection sites: VT, VB, AT, and AB. At each site, samples of leaves of vegetative broom and healthy leaves were collected from the same plant, with 12 plants, totaling 24 samples. The sampling period was January 2019, in the summer season. ${ }^{21}$

\section{Instrumentation}

Nutrient concentrations in the samples were determined using an inductively coupled plasma optical emission spectrometer (ICP OES), model 710-ES (Varian, Mulgrave, Australia), containing a concentric OneNeb nebulizer (Agilent Technologies, Santa Clara, USA), a cyclonic spray chamber (Varian, Mulgrave, Australia), a torch with an axial configuration (Varian, Mulgrave, Australia), and a charge-coupled device (CCD). Operating conditions were determined by the manufacturer, with radio frequency power $(1.3 \mathrm{~kW})$, nebulizer pressure $(150 \mathrm{kPa})$, plasma argon flow rate $\left(15 \mathrm{~L} \mathrm{~min}^{-1}\right)$, and argon auxiliary flow rate $\left(1.5 \mathrm{~L} \mathrm{~min}^{-1}\right)$. Optical emission lines $(\mathrm{nm})$ were: Cu I 327.395; Fe II 238.204; Mn II 257.610; Ni II 231.604; Zn I 213.857; Ca II 373.690; Mg II 280.270; K I 766.491; P I 213.618; S I 181.972. N was determined using the Kjeldahl method. ${ }^{22}$ Once the samples were digested, they were distilled in a semiautomatic distiller (Kjeldahl, Diadema, Brazil) and subsequently titrated with a standard solution of sulfuric acid $\left(0.1 \mathrm{~mol} \mathrm{~L}^{-1}\right)$. Two digestion blocks were used, a TE-007MP with temperature control (Tecnal, Piracicaba, Brazil), for the wet digestion of the samples and certified reference material to determine $\mathrm{Ca}, \mathrm{K}, \mathrm{Mg}, \mathrm{P}, \mathrm{S}$, $\mathrm{Cu}, \mathrm{Fe}, \mathrm{Mn}, \mathrm{Ni}$, and $\mathrm{Zn}$, and a Quimis micro digester with temperature control (Kjeldahl, Diadema, Brazil), for the wet digestion of samples and certified reference material to determine N. An AX200 analytical scale (Shimadzu, Kyoto, Japan) was used for weighing. An MA033/480 sterilization and drying oven with temperature control (Marconi, Piracicaba, Brazil) was used to dry the samples. Lastly, a food grinder (Philips, Barueri, Brazil) was used to grind the samples.

\section{Reagents and solutions}

All the reagents used were analytical grade and the solutions were prepared using ultrapure water (resistivity of $18.2 \mathrm{M} \Omega \mathrm{cm}$ ), obtained with a purification system (Milli-Q, Bedford, USA) and a deionizer (Permution, Curitiba, Brazil). A 5\% ( $\left.\mathrm{v} \mathrm{v}^{-1}\right)$ hydrochloric acid solution (EMSURE, Merck, Darmstadt, Germany) were used in the decontamination of the decomposition glass tubes used in the Kjeldhal method. Nitric acid 65\% v v ${ }^{-1}$ (EMSURE, 
Merck, Darmstadt, Germany) and hydrogen peroxide $30 \% \mathrm{v} \mathrm{v}^{-1}$ (EMSURE, Merck, Darmstadt, Germany), were used in the samples digestion for posterior ICP OES analysis.

For $\mathrm{N}$ determination, the samples were digested using the Kjeldahl method using sulfuric acid 95-97\% (Merck, Darmstadt, Germany), and a mixture (10:1) composed of $100 \mathrm{~g}$ of potassium sulfate P.A.-ACS (practical gradeAmerican Chemical Society, Química Moderna, Barueri, Brazil), and $10 \mathrm{~g}$ of copper sulfate P.A.-ACS (Biotec, Paraná, Brazil). Sodium hydroxide solution $13 \mathrm{~mol} \mathrm{~L}^{-1}$ (Biotec, Paraná, Brazil) was added in the distillation process. Boric acid (ACS, Química Moderna, Barueri, Brazil), was used to standardize a $2 \%\left(\mathrm{~m} \mathrm{v}^{-1}\right)$ solution containing $0.1 \mathrm{~mol} \mathrm{~L}^{-1}$ sodium hydroxide solution. An indicator was composed by methyl red solution $0.1 \%$ (Química Moderna, Barueri, Brazil), bromocresol green solution 0.1\% (ACS, Química Moderna, Barueri, Brazil), and, finally the volume was completed with ethyl alcohol 99.8\% P.A. (Biotec, Paraná, Brazil). A solution composed by $\mathrm{NaOH}$ solution and this indicator was used to collect the droplets of distilled solution. After distillation, the ammonia borate solution was titrated with a standard solution of sulfuric acid $0.0969 \mathrm{~mol} \mathrm{~L}^{-1}$, prepared from $95-97 \%$ sulfuric acid (ENSURE, Merck, Darmstadt, Germany). Standard solutions $\left(1000 \mathrm{mg} \mathrm{L}^{-1}\right)$ of the studied metals (Merck, Darmstadt, Germany) were used to prepare the analytical curves and a multi-element standard solution (High-Purity Standards, South Carolina, USA) was used to calibrate the optical system of the ICP OES. Sodium hydroxide (Biotec, Paraná, Brazil) and potassium biphthalate (Biotec, Paraná, Brazil) solutions were used for determining residual acidity and in the titration associated to the Kjeldahl method. All glassware and containers were previously decontaminated in baths containing $10 \% \mathrm{v} \mathrm{v}^{-1}$ nitric acid for $24 \mathrm{~h}$ or $10 \% \mathrm{v} \mathrm{v}^{-1}$ hydrochloric acid also for $24 \mathrm{~h}$, thoroughly rinsed with deionized water, and dried in a dust-free environment.

\section{Pre-treatment of samples}

The samples were triple washed with detergent solution $\left(0.1 \%, \mathrm{v} \mathrm{v}^{-1}\right)$ and rinsed with ultrapure water. ${ }^{23}$ Any excess water was drained, the samples were air-dried, weighed on an analytical balance and packed in identified paper bags. After this stage, the samples were placed in a sterilization and drying oven with forced air circulation for $72 \mathrm{~h}$ between 65 and $70{ }^{\circ} \mathrm{C}$ and weighed on an analytical scale until they reached constant mass. ${ }^{21}$ In the next step, the samples were crushed, sieved through a 120-mesh, and stored in plastic containers with a lid.
Samples digestion for further elements determination by ICP OES

This procedure was performed according to an adapted methodology. ${ }^{24-26} \mathrm{~A} 250 \mathrm{mg}$ of the sample was weighed and transferred to the digestion tube, after which $3.0 \mathrm{~mL}$ of nitric acid $\left(\mathrm{HNO}_{3}\right.$ P.A. $\left.65 \% \mathrm{v} \mathrm{v}^{-1}\right)$ plus $2.0 \mathrm{~mL}$ of hydrogen peroxide $\left(\mathrm{H}_{2} \mathrm{O}_{2}\right.$ P.A. $\left.30 \% \mathrm{~m} \mathrm{v}^{-1}\right)$ were added. The digestion tubes were taken to the digestion block for approximately $2 \mathrm{~h}$, at a temperature of $120 \pm 5{ }^{\circ} \mathrm{C}$ until obtaining a clear digest without the presence of particles. This procedure was performed in triplicate for each sample. Then, the tubes were removed from the digestion block and cooled at room temperature. The digested samples were transferred to $50 \mathrm{~mL}$ falcon tubes, filled with ultrapure water until reaching a volume of $20 \mathrm{~mL}$ and stored at $4{ }^{\circ} \mathrm{C}$ in a refrigerator until the moment of reading. For N, K, P, Ca, $\mathrm{Mg}$ and $\mathrm{S}$ determination, these solutions were diluted five times before analysis. Solutions containing all the reagents in the absence of the sample were prepared analogously to be evaluated as a blank test.

\section{Kjeldahl method for nitrogen determination}

\section{Sample digestion}

The procedure was performed according to the methodology from Nogueira et al..$^{22}$ A $250 \mathrm{mg}$ mass of the sample was weighed and transferred to the digestion tube. Then, $0.7 \mathrm{~g}$ of the catalytic mixture (potassium sulfate and copper sulfate $10: 1$ ) plus $2.5 \mathrm{~mL}$ of sulfuric acid $\left(\mathrm{H}_{2} \mathrm{SO}_{4}\right.$ P.A. $\left.95-97 \% \mathrm{v} \mathrm{v}^{-1}\right)$ were added and digested in the digestion block until the solution have turned slightly green. The procedure was performed for approximately $4 \mathrm{~h}$, at an initial temperature of $50^{\circ} \mathrm{C}$, gradually increasing to $350 \pm 5^{\circ} \mathrm{C}$. This procedure was performed in triplicate for each sample. Subsequently, the tubes were removed from the digestion block and cooled to room temperature, after which $10 \mathrm{~mL}$ of ultrapure water was added to prevent crystallization.

\section{Distillation}

The tubes containing digested samples were subjected to distillation, in which the distiller output was transferred to a $10 \mathrm{~mL}$ of boric acid solution, contained in a $125-\mathrm{mL}$ Erlenmeyer flask.

\section{Titration}

Then, $10 \mathrm{~mL}$ of $13 \mathrm{~mol} \mathrm{~L}^{-1}$ sodium hydroxide solution was added to the digested samples followed by immediate distillation, collecting approximately $35 \mathrm{~mL}$ of the distillate. Solutions containing all the reagents in the 
absence of the sample were prepared analogously to be evaluated as a blank test.

\section{Analytical validation and statistical analysis}

To validate the adopted analytical procedure, the following merit parameters were evaluated: limit of detection (LOD), limit of quantification (LOQ), precision (expressed as repeatability, RSD, in percentage), linearity (expressed as coefficient of determination), and accuracy. The LOD and LOQ for each metal were calculated based on the standard deviation, $\mathrm{S}_{\mathrm{br}}$, for 10 blank replicates, for $\mathrm{LOD}=\mathrm{BV}+3 \mathrm{~S}_{\mathrm{br}}$ and $\mathrm{LOQ}=\mathrm{BV}+10 \mathrm{~S}_{\mathrm{br}}$, where $\mathrm{BV}$ is the mean of the black values. Precisions were measured as RSD of ten determinations at two points of the analytical curve ( 0.5 and $\left.20 \mathrm{mg} \mathrm{L}^{-1}\right)$. Accuracy was obtained by analysis of certified reference materials (Brachiaria brizantha cv. Marandu RM-Agro E1001a from Embrapa Pecuária Sudeste and 1515 apple leaves from National Institute of Standards and Technology, NIST), where approximately $250 \mathrm{mg}$ of reference material was weighed and subjected to the same sample decomposition protocol.

The data obtained were tabulated and subjected to independent Student's $t$-test. They were also self-scaled and submitted to principal component analysis (PCA). The software Statistica, version $13.3,{ }^{27}$ was used.

\section{Results and Discussion}

\section{Analytical validation}

The method was evaluated to ensure basic parameters such as limit of detection, limit of quantification, precision, linearity, and accuracy. The method was found to have adequate analytical characteristics (Table 1).
Accuracy of the method was verified by analyzing two types of certified reference material, compatible with the type of sample studied (Table 2), using the Kjeldahl method for nitrogen and the ICP OES for the other nutrients. Some elements have presented a very high dispersion. This probably could be attributed to some heterogeneity in the samples. According to the paired Student's $t$-test, at the $95 \%$ confidence level, the values found by analyzing the reference material and the certified values do not show a significant difference (RM-Agro E1001a $t=1.76>0.05$; NIST 1515 apple leaves $t=1.73>0.06$ ).

According to the normalized error calculations, the values found in the analysis of the studied materials and the values of the certified reference materials have satisfactory accuracy, as the normalized error is less than or equal to 1 for most nutrients, except nitrogen and phosphorus in NIST 1515. The recovered values are between 80 to $110 \%$ for most nutrients, with the exception of calcium in RM-Agro, which has a $113 \%$ recovery. By the paired Student's $t$-test, at the $95 \%$ confidence level, there is no significant difference between the data set (RM-Agro $t=1.76>0.05$ and for NIST $1515 t=1.73>0.06$ ).

\section{Nutrient concentration as a function of plant-fungal} interaction

An infection of witch's broom is known to reduce the productivity of cocoa trees, and the chemical analysis of the leaves showed that this plant-fungal interaction is reflected in nutrient concentration and may be related to the increase or decrease of nutrients in the leaf tissue (Tables 3 and 4).

Among the macronutrients in the leaves of vegetative broom, the four highest concentrations were of $\mathrm{N}, \mathrm{K}, \mathrm{Mg}$, and $\mathrm{Ca}$ and the two lowest concentrations were of $\mathrm{P}$ and $\mathrm{S}$ (Table 3). Similarly, in healthy leaves, the four highest

Table 1. Analytical parameters of the method for determining essential nutrients in cocoa tree leaves

\begin{tabular}{|c|c|c|c|c|c|}
\hline Nutrient & $\mathrm{LOD} /\left(\mathrm{mg} \mathrm{kg}^{-1}\right)$ & $\mathrm{LOQ} /\left(\mathrm{mg} \mathrm{kg}^{-1}\right)$ & $\mathrm{RSD} / \%$ & $\mathrm{R}^{2}$ & Linear range / $\left(\mathrm{mg} \mathrm{L}^{-1}\right)$ \\
\hline $\mathrm{Ca}$ & 0.197 & 0.591 & 1.10 & 0.9995 & $4.00-50.0$ \\
\hline $\mathrm{K}$ & 0.243 & 0.729 & 0.61 & 0.9997 & $4.00-80.0$ \\
\hline $\mathrm{Mg}$ & 0.218 & 0.653 & 0.64 & 0.9991 & $4.00-30.0$ \\
\hline $\mathrm{P}$ & 0.277 & 0.830 & 1.45 & 0.9999 & $2.00-40.0$ \\
\hline $\mathrm{S}$ & 1.13 & 3.38 & 1.44 & 0.9998 & $2.00-40.0$ \\
\hline $\mathrm{Cu}$ & 0.453 & 1.36 & 0.70 & 0.9999 & $0.0100-2.00$ \\
\hline $\mathrm{Fe}$ & 0.643 & 1.93 & 6.08 & 0.9997 & $0.200-4.00$ \\
\hline $\mathrm{Mn}$ & 0.0530 & 0.159 & 1.43 & 0.9999 & $0.0100-2.00$ \\
\hline $\mathrm{Ni}$ & 0.247 & 0.742 & 0.67 & 0.9998 & $0.0100-2.00$ \\
\hline $\mathrm{Zn}$ & 0.613 & 1.84 & 0.64 & 0.9996 & $0.0100-2.00$ \\
\hline
\end{tabular}

LOD: limit of detection; LOQ: limit of quantification; RSD: relative standard deviation ( $\mathrm{n}=10$ ) for concentrations of $0.5 \mathrm{mg} \mathrm{L}^{-1}$ for $\mathrm{Cu}, \mathrm{Fe}, \mathrm{Mn}, \mathrm{Ni}, \mathrm{Zn}$ and $20 \mathrm{mg} \mathrm{L}^{-1}$ for $\mathrm{Ca}, \mathrm{K}, \mathrm{Mg}, \mathrm{P}$ and $\mathrm{S} ; \mathrm{R}^{2}$ : coefficient of determination. Elemental concentrations were calculated to sample mass of $250 \mathrm{mg}$. 
Table 2. Results (mean \pm standard deviation) obtained for analysis of certified reference materials Brachiaria brizantha cv. Marandu RM-Agro E1001 and NIST 1515 apple leaves

\begin{tabular}{|c|c|c|c|c|c|}
\hline Nutrient & Material & Certified value & Value found & Normalized error & Agreement / \% \\
\hline $\mathrm{Ca} /\left(\mathrm{g} \mathrm{kg}^{-1}\right)$ & RM-Agro & $4.37 \pm 0.58$ & $4.93 \pm 2.2$ & 0.2 & 113 \\
\hline $\mathrm{K} /\left(\mathrm{g} \mathrm{kg}^{-1}\right)$ & RM-Agro & $12.0 \pm 2.40$ & $11.4 \pm 4.4$ & 0.1 & 95 \\
\hline $\mathrm{Mg} /\left(\mathrm{g} \mathrm{kg}^{-1}\right)$ & RM-Agro & $2.95 \pm 0.44$ & $3.18 \pm 0.73$ & 0.2 & 108 \\
\hline $\mathrm{P} /\left(\mathrm{g} \mathrm{kg}^{-1}\right)$ & RM-Agro & $0.65 \pm 0.19$ & $0.58 \pm 0.28$ & 0.2 & 89 \\
\hline $\mathrm{Cu} /\left(\mathrm{mg} \mathrm{kg}^{-1}\right)$ & RM-Agro & $4.0 \pm 0.7$ & $3.87 \pm 0.01$ & 0.1 & 97 \\
\hline $\mathrm{Fe} /\left(\mathrm{mg} \mathrm{kg}^{-1}\right)$ & RM-Agro & $91 \pm 13$ & $76 \pm 11$ & 0.8 & 83 \\
\hline $\mathrm{Mn} /\left(\mathrm{mg} \mathrm{kg}^{-1}\right)$ & RM-Agro & $76.0 \pm 18.5$ & $82.17 \pm 0.01$ & 0.3 & 108 \\
\hline $\mathrm{Zn} /\left(\mathrm{mg} \mathrm{kg}^{-1}\right)$ & RM-Agro & $9.9 \pm 1.6$ & $10.38 \pm 0.01$ & 0.3 & 105 \\
\hline $\mathrm{Ca} /\left(\mathrm{mg} \mathrm{kg}^{-1}\right)$ & NIST1515 & $15250 \pm 100$ & $14560 \pm 76$ & 0.8 & 95 \\
\hline $\mathrm{K} /\left(\mathrm{mg} \mathrm{kg}^{-1}\right)$ & NIST1515 & $16080 \pm 210$ & $15192 \pm 89$ & 0.9 & 94 \\
\hline $\mathrm{Mg} /\left(\mathrm{mg} \mathrm{kg}^{-1}\right)$ & NIST1515 & $2710 \pm 120$ & $2569 \pm 24$ & 0.5 & 95 \\
\hline $\mathrm{P} /\left(\mathrm{mg} \mathrm{kg}^{-1}\right)$ & NIST1515 & $1593 \pm 68$ & $1477 \pm 66$ & 1.2 & 93 \\
\hline $\mathrm{S} /\left(\mathrm{mg} \mathrm{kg}^{-1}\right)$ & NIST1515 & $1800 \pm 66$ & $1777 \pm 12$ & 0.2 & 99 \\
\hline $\mathrm{Cu} /\left(\mathrm{mg} \mathrm{kg}^{-1}\right)$ & NIST1515 & $5.69 \pm 0.13$ & $5.35 \pm 0.30$ & 1.0 & 94 \\
\hline $\mathrm{Fe} /\left(\mathrm{mg} \mathrm{kg}^{-1}\right)$ & NIST1515 & $82.7 \pm 2.6$ & $75.1 \pm 6.9$ & 1.0 & 91 \\
\hline $\mathrm{Mn} /\left(\mathrm{mg} \mathrm{kg}^{-1}\right)$ & NIST1515 & $54.1 \pm 1.1$ & $53.5 \pm 2.8$ & 0.2 & 99 \\
\hline $\mathrm{Ni} /\left(\mathrm{mg} \mathrm{kg}^{-1}\right)$ & NIST1515 & $0.936 \pm 0.094$ & $0.95 \pm 0.05$ & 0.1 & 101 \\
\hline $\mathrm{Zn} /\left(\mathrm{mg} \mathrm{kg}^{-1}\right)$ & NIST1515 & $12.45 \pm 0.43$ & $13.4 \pm 0.9$ & 0.9 & 108 \\
\hline $\mathrm{N} /\left(\mathrm{mg} \mathrm{kg}^{-1}\right)$ & NIST1515 & $22990 \pm 900$ & $20541 \pm 1387$ & 1.4 & 89 \\
\hline
\end{tabular}

$95 \%$ confidence level; $\mathrm{n}=3$.

Table 3. Nutrient concentrations (mean \pm standard deviation) in leaves of vegetative broom of cocoa trees, collected from four plants

\begin{tabular}{lccccc}
\hline & $\mathrm{AB}$ & $\mathrm{AT}$ & $\mathrm{VB}$ & $\mathrm{VT}$ & Average \\
\hline $\mathrm{Ca} /\left(\mathrm{g} \mathrm{kg}^{-1}\right)$ & $4.03 \pm 1.40$ & $1.35 \pm 0.14$ & $1.66 \pm 0.20$ & $1.69 \pm 0.23$ & $2.18 \pm 0.50$ \\
$\mathrm{~K} /\left(\mathrm{g} \mathrm{kg}^{-1}\right)$ & $23.87 \pm 0.91$ & $17.95 \pm 0.97$ & $19.06 \pm 1.20$ & $17.45 \pm 0.84$ & $19.58 \pm 1.10$ \\
$\mathrm{Mg} /\left(\mathrm{g} \mathrm{kg}^{-1}\right)$ & $2.87 \pm 0.32$ & $2.53 \pm 0.12$ & $3.30 \pm 0.28$ & $2.82 \pm 0.17$ & $2.88 \pm 0.21$ \\
$\mathrm{P} /\left(\mathrm{g} \mathrm{kg}^{-1}\right)$ & $0.23 \pm 0.01$ & $1.98 \pm 0.12$ & $0.19 \pm 0.01$ & $2.03 \pm 0.15$ & $1.11 \pm 0.27$ \\
$\mathrm{~S} /\left(\mathrm{g} \mathrm{kg}^{-1}\right)$ & $1.65 \pm 0.13$ & $1.62 \pm 0.08$ & $1.88 \pm 0.10$ & $1.76 \pm 0.06$ & $1.73 \pm 0.08$ \\
$\mathrm{~N} /\left(\mathrm{g} \mathrm{kg}^{-1}\right)$ & $19.39 \pm 0.77$ & $20.80 \pm 1.10$ & $19.53 \pm 1.20$ & $23.46 \pm 0.87$ & $20.79 \pm 0.95$ \\
$\mathrm{Cu} /\left(\mathrm{mg} \mathrm{kg}^{-1}\right)$ & $4.16 \pm 0.97$ & $14.62 \pm 3.00$ & $9.23 \pm 0.58$ & $11.28 \pm 0.99$ & $9.82 \pm 1.60$ \\
$\mathrm{Fe} /\left(\mathrm{mg} \mathrm{kg}^{-1}\right)$ & $6.44 \pm 2.9$ & $21.83 \pm 2.6$ & $25.74 \pm 1.8$ & $23.03 \pm 1.1$ & $19.26 \pm 2.7$ \\
$\mathrm{Mn} /\left(\mathrm{mg} \mathrm{kg}^{-1}\right)$ & $15.0 \pm 8.7$ & $52 \pm 13.0$ & $14.2 \pm 1.7$ & $31.4 \pm 3.4$ & $28.1 \pm 8.3$ \\
$\mathrm{Ni} /\left(\mathrm{mg} \mathrm{kg}^{-1}\right)$ & $1.10 \pm 0.20$ & $2.27 \pm 0.12$ & $1.47 \pm 0.14$ & $1.75 \pm 0.14$ & $1.60 \pm 0.20$ \\
$\mathrm{Zn} /\left(\mathrm{mg} \mathrm{kg}^{-1}\right)$ & $13.69 \pm 4.20$ & $26.45 \pm 2.12$ & $25.42 \pm 2.18$ & $36.17 \pm 3.25$ & $25.43 \pm 3.48$ \\
\hline
\end{tabular}

$95 \%$ confidence level; $\mathrm{n}=3$. V, A: two farms, coded as area $\mathrm{V}$ and area $\mathrm{A} ; \mathrm{B}$, T: two cocoa plantations, named site $\mathrm{T}$ and site $\mathrm{B}$.

concentrations were of $\mathrm{N}, \mathrm{K}, \mathrm{Ca}$, and $\mathrm{Mg}$ and the two lowest concentrations were of $\mathrm{P}$ and $\mathrm{S}$ (Table 4). Among the micronutrients in the leaves of vegetative broom, the three highest average concentrations were of $\mathrm{Mn}, \mathrm{Zn}$, and $\mathrm{Fe}$ and the two lowest average concentrations were of $\mathrm{Cu}$ and $\mathrm{Ni}$ (Table 3). The same averages were found in the healthy leaves, in which the three highest concentrations were of $\mathrm{Mn}, \mathrm{Fe}$, and $\mathrm{Zn}$ and the two lowest concentrations were of $\mathrm{Cu}$ and $\mathrm{Ni}$ (Table 4).

The macronutrients $\mathrm{Mg}$ and $\mathrm{Ca}$ change position in order of magnitude, that is, concentration is $\mathrm{P}<\mathrm{S}<\mathrm{Ca}<$ $\mathrm{Mg}<\mathrm{K}<\mathrm{N}$ in the leaves of vegetative broom and $\mathrm{P}<\mathrm{S}<$ $\mathrm{Mg}<\mathrm{Ca}<\mathrm{K}<\mathrm{N}$ in the healthy leaves. Moreover, the micronutrients $\mathrm{Fe}$ and $\mathrm{Zn}$ change position in order of 
Table 4. Nutrient concentrations (mean \pm standard deviation) in healthy leaves of cocoa trees, collected from four plants

\begin{tabular}{|c|c|c|c|c|c|}
\hline & $\mathrm{AB}$ & AT & VB & VT & Average \\
\hline $\mathrm{Ca} /\left(\mathrm{g} \mathrm{kg}^{-1}\right)$ & $6.73 \pm 1.5$ & $5.84 \pm 0.68$ & $5.82 \pm 1.00$ & $5.80 \pm 0.54$ & $6.05 \pm 0.71$ \\
\hline $\mathrm{K} /\left(\mathrm{g} \mathrm{kg}^{-1}\right)$ & $24.06 \pm 1.8$ & $17.31 \pm 1.2$ & $18.88 \pm 1.9$ & $18.83 \pm 1.4$ & $19.77 \pm 1.5$ \\
\hline $\mathrm{Mg} /\left(\mathrm{g} \mathrm{kg}^{-1}\right)$ & $5.03 \pm 0.58$ & $5.61 \pm 0.43$ & $6.98 \pm 0.67$ & $6.20 \pm 0.37$ & $5.95 \pm 0.48$ \\
\hline $\mathrm{P} /\left(\mathrm{g} \mathrm{kg}^{-1}\right)$ & $0.15 \pm 0.01$ & $1.27 \pm 0.09$ & $0.13 \pm 0.01$ & $1.16 \pm 0.07$ & $0.68 \pm 0.16$ \\
\hline $\mathrm{S} /\left(\mathrm{g} \mathrm{kg}^{-1}\right)$ & $1.74 \pm 0.17$ & $1.77 \pm 0.11$ & $2.03 \pm 0.09$ & $2.00 \pm 0.10$ & $1.89 \pm 0.11$ \\
\hline $\mathrm{N} /\left(\mathrm{g} \mathrm{kg}^{-1}\right)$ & $18.4 \pm 0.51$ & $20.1 \pm 0.66$ & $19.1 \pm 0.39$ & $22.2 \pm 0.62$ & $19.9 \pm 0.60$ \\
\hline $\mathrm{Cu} /\left(\mathrm{mg} \mathrm{kg}^{-1}\right)$ & $3.43 \pm 0.73$ & $7.63 \pm 0.41$ & $6.86 \pm 0.40$ & $6.61 \pm 0.27$ & $6.13 \pm 0.62$ \\
\hline $\mathrm{Fe} /\left(\mathrm{mg} \mathrm{kg}^{-1}\right)$ & $8.12 \pm 2.6$ & $28.5 \pm 2.1$ & $32.9 \pm 1.7$ & $36.9 \pm 2.7$ & $26.62 \pm 3.7$ \\
\hline $\mathrm{Mn} /\left(\mathrm{mg} \mathrm{kg}^{-1}\right)$ & $40.7 \pm 13$ & $254 \pm 41$ & $47.4 \pm 7.96$ & $153 \pm 18$ & $124 \pm 33$ \\
\hline $\mathrm{Ni} /\left(\mathrm{mg} \mathrm{kg}^{-1}\right)$ & $1.16 \pm 0.24$ & $4.00 \pm 0.28$ & $1.88 \pm 0.13$ & $2.45 \pm 0.19$ & $2.37 \pm 3.10$ \\
\hline $\mathrm{Zn} /\left(\mathrm{mg} \mathrm{kg}^{-1}\right)$ & $15.5 \pm 4.4$ & $26.0 \pm 3.3$ & $20.6 \pm 1.6$ & $29.8 \pm 2.8$ & $23.0 \pm 3.1$ \\
\hline
\end{tabular}

95\% confidence level; $\mathrm{n}=3$. V, A: two farms, coded as area V and area A; B, T: two cocoa plantations, named site $\mathrm{T}$ and site $\mathrm{B}$.

magnitude, where concentration is $\mathrm{Ni}<\mathrm{Cu}<\mathrm{Fe}<\mathrm{Zn}<$ $\mathrm{Mn}$ in leaves of vegetative broom and $\mathrm{Ni}<\mathrm{Cu}<\mathrm{Zn}<\mathrm{Fe}<$ $\mathrm{Mn}$ in healthy leaves. The micronutrient $\mathrm{Mn}$, as expected in plant samples, had the highest concentrations in both types of leaves and, among the macronutrients, $\mathrm{N}$ and $\mathrm{K}$ presented the highest concentrations (Tables 3 and 4).

The independent Student's $t$-test compared the concentration of the same nutrient between both types of leaves according to the sample site. The result showed that the concentration of $\mathrm{Ca}, \mathrm{Mg}, \mathrm{S}, \mathrm{P}, \mathrm{Cu}, \mathrm{Fe}, \mathrm{Mn}$, and $\mathrm{Ni}$ changed in relation to the presence or absence of infection by $M$. perniciosa, while $\mathrm{K}, \mathrm{N}$, and Zn did not show any change (Table S1 presented in Supplementary Information (SI) section).

There was no significant difference in nitrogen concentration between the two types of leaves in any of the samples (Table S1, SI section). Nitrogen is an essential component of nucleic acids, chlorophyll, amino acids, among others. However, an excess of nitrogen and, consequently, of nitrogen components, can cause a mineral imbalance that affects the plant-fungal relationship by decreasing the plant's resistance. ${ }^{28}$

In addition, there was no statistically significant difference in $\mathrm{K}, \mathrm{Zn}$ and $\mathrm{S}$ concentrations between the healthy leaves and the leaves of vegetative broom in any of the samples (Table S1, SI section). Potassium is essential for the synthesis of cellulose in plants and its deficiency may make the cell wall permeable, which can cause the apoplast to contain high concentrations of sugars and amino acids, which would be a favorable environment for $M$. perniciosa since the fungus uses the apoplast to obtain nutrients in the biotrophic stage..$^{11,19,28}$ Sulfur is a component of glutathione, an antioxidant that combats compounds toxic to plants, which often results from biotic or abiotic stresses, such as those caused by pathogens. It is also known that $\mathrm{S}$ is a constituent nutrient of amino acids and proteins and actively participates in reactions involving nitrogen. ${ }^{23}$ Zinc plays an important role in physiological processes in plants, such as enzymatic cofactor, gene expression, and stability of the genetic material; moreover, in conditions of environmental stress, it helps regulate the expression of cell protection genes. ${ }^{29}$

There was a statistically significant difference in $\mathrm{Ca}$, $\mathrm{Mg}, \mathrm{Mn}, \mathrm{Ni}, \mathrm{Cu}, \mathrm{Fe}$ and $\mathrm{P}$ between the two types of leaves in all samples (Table S1, SI section). Calcium, Mg, Mn and $\mathrm{Fe}$ were found in greater concentration in healthy leaves then the sick leaves. On the other hand, P, Ni and $\mathrm{Cu}$ concentrations were higher in broom leaves (Tables 3 and 4).

Calcium is an inhibitor of enzymes released by fungi in the invasion process. These enzymes break down the plant cell wall and middle lamella, which have this metal in their constitution. Then it presents an inverse relationship between their concentrations in plant tissues and resistance to invasions. ${ }^{28}$ Calcium also acts as an intracellular messenger of extracellular stress processes in the plant, as in the case of chitinase-like proteins sensitive to this element, for example. ${ }^{30}$ If calcium deficiency occurs, the membranes become fragile, can break and extravagates the intracellular content, which can be a source of food for parasites that are in the apoplast, as in the case of M. perniciosa in the biotrophic stage.

Healthy leaves has a more intense green coloration than leaves of vegetative broom. Since $\mathrm{Mg}$ forms the nucleus of the chlorophyll molecule, ${ }^{21,31}$ this may explain the different concentrations between healthy and sick leaves. Phosphorus is a constituent of molecules such as nucleotides, nucleic acids, lipids, and proteins; moreover, it functions as a 
messenger of mechanical stimuli and is essential in cell division. ${ }^{21,32}$ In pathogenic fungi, this nutrient is associated with changes in cell wall architecture, which is a form of resistance. ${ }^{20}$ In experiments with $M$. perniciosa, a regular growth in the molecular weight of $\mathrm{P}$ occurred during cultivation of the fungus. ${ }^{20}$ Therefore, it is suggested that the mycelial growth of the fungus and changes in its cell wall are related to the concentration differences of $\mathrm{P}$ between healthy and infected cocoa leaves.

The higher concentration of $\mathrm{Mn}$ in the healthy leaves ${ }^{21}$ can be explained based on the positive effect of $\mathrm{Mn}$ in protecting the plant against witch's broom by providing partial resistance to the disease. ${ }^{33}$ In addition, in plants, this nutrient has functions related to reducing damage from diseases. It acts as an activator of enzymes needed for the biosynthesis of secondary metabolites and participates in lignification processes and is toxic to the fungi. ${ }^{23}$

The concentration of $\mathrm{Ni}$ in leaves samples generally range from 0.05 to $10 \mathrm{mg} \mathrm{kg}^{-1}$ dry weight, ${ }^{34}$ which is within the range found in this study. Even in a small concentration, $\mathrm{Ni}$ is essential in the metabolism of nitrogen in plants. ${ }^{35}$ However, an accumulation of this metal in the diseased leaves was found in this study, probably due to the difficulty of excreting the excess of this metal.

The greater presence of $\mathrm{Cu}$ in the sick leaves may be linked to the disease resistance functions of this metal, such as participation in the production of defense and lignification compounds. Furthermore, during the infection of $M$. perniciosa in the leaf tissue of T. grandiflorum, a higher concentration of $\mathrm{Cu}$ was found in the sick leaves. ${ }^{18}$

Iron is a nutrient that participates in several stages of metabolism, such as cellular respiration, and protein and enzyme composition, and is critical for electron flow in photosynthesis. ${ }^{30,36}$ Therefore, healthy leaves shows a tendency to be greater.

In general, most mineral nutrients showed differences in concentration in the comparison between healthy leaves and leaves of vegetative broom. This difference is probably related to the functions these nutrients perform, whether in structural defense mechanisms and induction to resistance or in the constitution of defense molecules..$^{20,21,23,28,31,37}$ The results indicate a relationship between the infection of M. perniciosa and changes in nutritional concentration in the leaves of Theobroma cacao L., as concentrations of $\mathrm{Mg}$, $\mathrm{Ca}, \mathrm{S}, \mathrm{Fe}, \mathrm{Mn}$, and $\mathrm{Ni}$ were lower in the leaves of vegetative broom than in healthy leaves, while concentrations of $\mathrm{P}$ and $\mathrm{Cu}$ were lower in healthy leaves and higher in leaves of vegetative broom. In contrast, no association was found between fungus infection and changes in concentrations of $\mathrm{K}, \mathrm{N}$, and $\mathrm{Zn}$ in any of the samples.

\section{Distinctive nutrients in plant-fungal interaction}

PCA was used to extract information on differences in nutrient concentrations in the cocoa leaves. ${ }^{38,39}$ The analysis was applied to the information from the four collection sites, each with eleven quantified nutrients, taken from 12 samples of healthy leaves and 12 samples of leaves of vegetative broom.

PCA for the data from site VT showed that the first three components explain $82.03 \%$ of the total variation. The first component (PC1) has the largest contribution of the variables $\mathrm{Cu}, \mathrm{Fe}, \mathrm{Mn}, \mathrm{Ca}, \mathrm{Mg}$, and $\mathrm{P}$, representing $50.51 \%$ of the total variance. The second component (PC2) has the largest contribution of $\mathrm{Ni}, \mathrm{Zn}, \mathrm{K}$, and S, representing $20.75 \%$ of the total variance. Nitrogen strongly explains the third component (PC3), with $10.77 \%$ of the total variance. The scores of PC1 versus PC2 demonstrate a separation between the healthy leaves and leaves of vegetative broom (Figure 1a). $\mathrm{PC} 1$ in the loading graph shows that the nutrients $\mathrm{Zn}, \mathrm{Cu}, \mathrm{P}$, and $\mathrm{N}$ have positive vectors related to the separation of leaves of vegetative broom, while the nutrients $\mathrm{Ca}, \mathrm{Mg}, \mathrm{Mn}, \mathrm{Fe}$, $\mathrm{Ni}, \mathrm{S}$, and $\mathrm{K}$ have negative vectors related to the separation of healthy leaves (Figure 1b).

PCA for the data from site VB showed that the first three components explain $79.22 \%$ of the total variation. PC1 has the largest contribution of the variables $\mathrm{Cu}, \mathrm{Mn}, \mathrm{Ca}$, $\mathrm{Mg}$, and $\mathrm{P}$, explaining $46.07 \%$ of the total variance. PC2 is related to $\mathrm{Fe}, \mathrm{Ni}, \mathrm{S}$, and $\mathrm{N}$, representing $21.73 \%$ of the total variance. In PC3, nutrients $\mathrm{Zn}$ and $\mathrm{K}$ contribute most of the explanation of $11.42 \%$ of the total variance (Figure 1c). PC1 in the loading graph shows positive vectors for the nutrients $\mathrm{Zn}, \mathrm{Cu}, \mathrm{P}, \mathrm{K}$, and $\mathrm{N}$ related to the separation of the leaves of vegetative broom, while the nutrients $\mathrm{Ca}, \mathrm{Mg}, \mathrm{Mn}, \mathrm{Ni}$, $\mathrm{Fe}$, and $\mathrm{S}$ have negative vectors related to the separation of the healthy leaves (Figure 1d).

PCA for the data from site AT showed that the first three components explain $81.78 \%$ of the total variation. In PC1, there is a higher contribution of the variables $\mathrm{Mn}, \mathrm{Ni}, \mathrm{Ca}$, $\mathrm{Mg}$, and $\mathrm{P}$, representing $45.19 \%$ of the total variance. PC2 is characterized by $\mathrm{K}, \mathrm{S}$, and $\mathrm{N}$, representing $24.41 \%$ of the total variance. The nutrients $\mathrm{Cu}, \mathrm{Fe}$, and $\mathrm{Zn}$ strongly explain PC3, with $12.18 \%$ of the total variance (Figure 1e). PC1 in the loading graph has negative vectors for nutrients $\mathrm{K}, \mathrm{P}$, $\mathrm{Cu}$, and $\mathrm{N}$, related to the separation of leaves of vegetative broom, while the nutrients $\mathrm{Ni}, \mathrm{Ca}, \mathrm{Mg} \mathrm{Mn}, \mathrm{Fe}, \mathrm{S}$, and $\mathrm{Zn}$ have positive vectors related to the separation of healthy leaves (Figure 1f).

PCA for the data from site AB showed that the first three components explain $83.14 \%$ of the total variation. PC1 has the largest contribution of the variables $\mathrm{Cu}, \mathrm{Fe}$, $\mathrm{Mn}, \mathrm{Ni}$, and $\mathrm{Zn}$, explaining $43.15 \%$ of the total variance. 

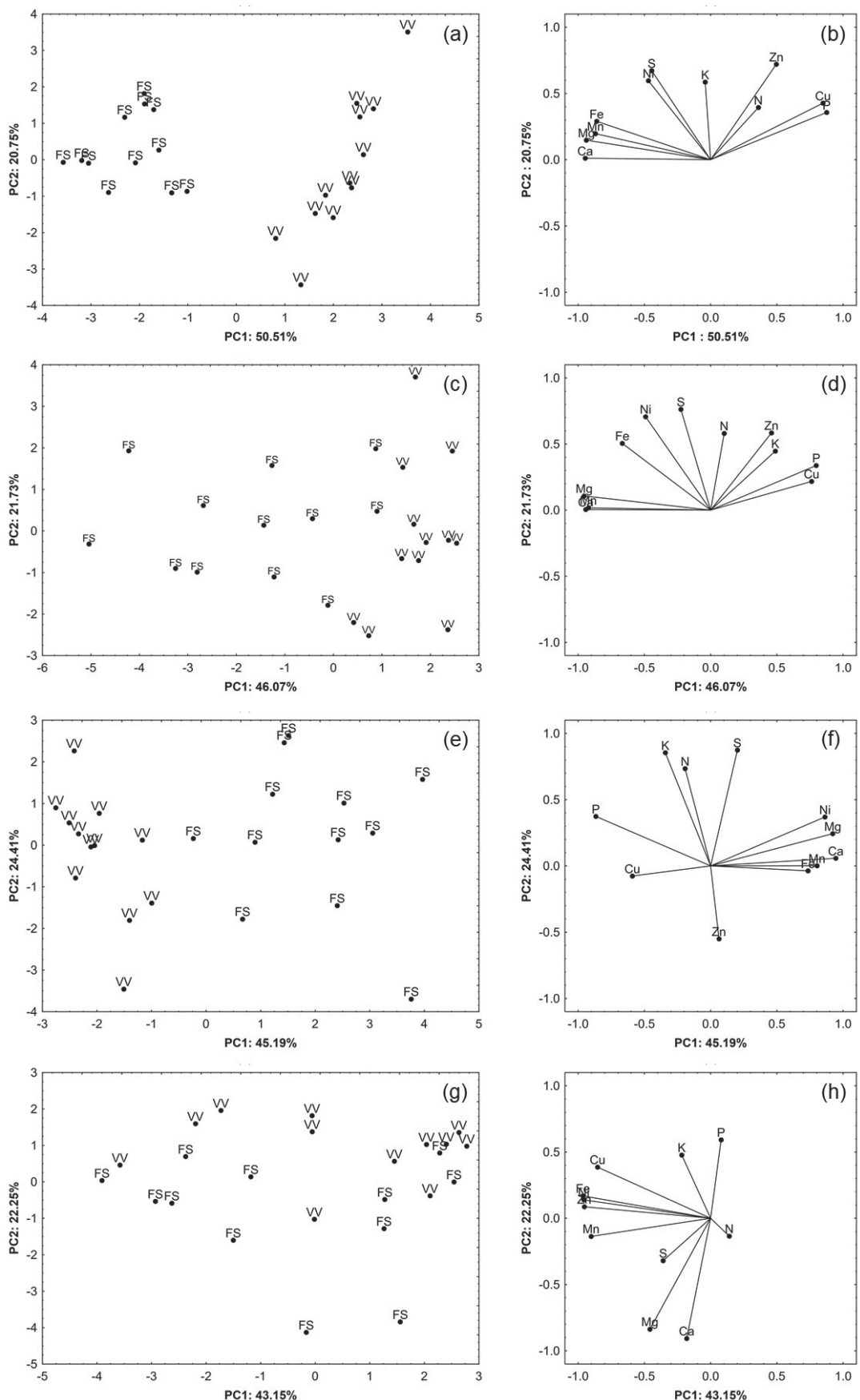

Figure 1. Principal component analysis for nutrient concentrations in cocoa leaves (FS: healthy leaf; VV: leaf of vegetative broom) from collection site VT (a and b), VB (c and d), AT (e and f) and AB (g and h) using 11 nutrients (Ca, Mg, K, P, S, N, Cu, Fe, Mn, Ni, and Zn), in 24 samples. (a, c, e, g) Score graphs; (b, d, f, h) loading graphs.

PC2 is related to $\mathrm{Ca}$ and $\mathrm{Mg}$, representing $22.25 \%$ of the total variance. In PC3, nutrients $\mathrm{K}, \mathrm{P}, \mathrm{S}$, and $\mathrm{N}$ contribute most to the explanation of $17.74 \%$ of the total variance (Figure 1g). In PC1, in the loading graph, the nutrients $\mathrm{Ca}, \mathrm{Mg}, \mathrm{Mn}, \mathrm{S}$, and $\mathrm{N}$ have negative vectors related to the separation of healthy leaves, while in $\mathrm{PC} 2$, the nutrients $\mathrm{Cu}, \mathrm{K}, \mathrm{P}, \mathrm{Fe}, \mathrm{Ni}$, and $\mathrm{Zn}$ have positive vectors related to the separation of leaves of vegetative broom (Figure 1h).

The sum of the first two principal components, according to the collection site, shows that they explain between 65 and $71 \%$ of the variance of the data, with a result per site of $\mathrm{AB} 65.40 \%$ (Figures $1 \mathrm{~g}$ and $1 \mathrm{~h}$ ), VB $67.80 \%$ (Figures 1c and 1d), AT $69.60 \%$ (Figures 1e and 1f), and VT $71.26 \%$ (Figures 1a and 1b). There was an amplitude of $6 \%$ which can arise from several factors that affect in the nutrient concentration in the leaves.

PCA also showed a reduction in data dimensions; the PCs demonstrate separation or tendency of separation 
between healthy leaves and leaves of vegetative broom, ${ }^{26,40,41}$ due to the difference in nutrient concentration. Based on the analysis of the graphic vectors, it can be seen that $\mathrm{Ca}$, $\mathrm{Mg}, \mathrm{P}, \mathrm{Cu}, \mathrm{Mn}, \mathrm{Fe}$, and $\mathrm{Ni}$ are more associated with the distinction of leaf types. In contrast, N, K, S, and Zn are less associated with this distinction, as they did not always show vectors aimed at separating leaves of vegetative broom from healthy leaves (Figures 1b, 1d, 1f and 1h).

\section{Conclusions}

This study showed that cacao leaves affected by the fungus Moniliophthora perniciosa have alterations in their levels of mineral nutrients in relation to healthy leaves. Healthy leaves have higher concentrations of $\mathrm{Ca}, \mathrm{Mg}, \mathrm{S}, \mathrm{Mn}, \mathrm{Ni}$ and $\mathrm{Fe}$ while diseased leaves have higher concentrations of $\mathrm{P}$ and $\mathrm{Cu}$. Zinc, $\mathrm{K}$ and $\mathrm{N}$ did not show statistically significant differences between healthy leaves and those affected by the fungus. PCA also evidence tendency of separation between the two types of leaves based on nutrient separation. These differences may be related to the functions that nutrients perform in the plant, in the fungus, and in plant-fungal interaction. It should be noted that the results do not synthesize all the perspectives of analysis. Therefore, further studies should seek to precisely identify the physiological age of leaves and possible differences in the mobility of nutrients for the development of infection and verify whether the effects of a smaller accumulation of biomass in the infected leaf can interfere in nutrient concentration. The information produced in the present study helps identify plant nutrition strategies for resistance to the pathogen and provides further knowledge for the practical control of witch's broom.

\section{Supplementary Information}

Supplementary information is available free of charge at http://jbcs.sbq.org.br as PDF file.

\section{Acknowledgments}

Authors acknowledge the financial support of the Fundação de Amparo à Pesquisa do Estado da Bahia (FAPESB), Universidade Estadual de Santa Cruz and Universidade Estadual do Sudoeste da Bahia.

\section{Author Contributions}

Hélio R. Sousa Filho was responsible for development of the experiments and preparation of the first version (this article is derived from his doctorate degree work); Vinnícius H. C. da Silva for assistance in the development of the experiments; André L. S. da Silva Junior for assistance in the development of the experiments; Juscelia P. S. Alves for assistance in the development of the experiments and writing of some sections; Gregório M. Santana for writing of some manuscript sections and final formatting; José O. de Souza Júnior for statistical analysis and review of the final manuscript; Marcos A. Bezerra and Raildo M. de Jesus for guidance of developed work and coordination of manuscript writing.

\section{References}

1. Van Vliet, J. A.; Giller, K. E.; Adv. Agron. 2017, 141, 185.

2. Fiorin, G. L.; Sanchez-Vallet, A.; Thomazella, D. P. T.; do Prado, P. F. V.; do Nascimento, L. C.; Figueira, A. V. O.; Thomma, B. P. H. J.; Pereira, G. A. G.; Teixeira, P. J. P. L.; Curr. Biol. 2018, $28,3023$.

3. International Cocoa Organization (ICCO); Annual Report 2014/2015; ICCO: Côte d'Ivoire, 2017.

4. Ploetz, R. In Cacao Diseases: A History of Old Enemies and New Encounters, $1^{\text {st }}$ ed.; Bailey, B. A.; Meinhardt, L.W., eds.; Springer: Switzerland, 2016.

5. https://sidra.ibge.gov.br/tabela/1613, accessed in August 2020.

6. Rocha, L. B.; A Região Cacaueira da Bahia - dos Coronéis à Vassoura-de-Bruxa: Saga, Percepção, Representação, $1^{\text {st }}$ ed.; Editus: Ilhéus, Brazil, 2008.

7. Piasentin, F. B.; Saito, C. H.; Estudo Debate 2012, 19, 63.

8. Chiapetti, J. In Cacau Cultivo Pesquisa e Inovação, $1^{\text {st }} \mathrm{ed}$.; de Souza Jr., J. O., ed.; Editus: Ilhéus, Brazil, 2018, p. 13.

9. Bolton, M. D.; Thomma, B. P. H. J.; Mol. Plant Pathol. 2008, $72,104$.

10. Teixeira, P. J. P. L.; Thomazella, D. P. T.; Pereira, G. A. G.; PLoS Pathog. 2015, 11, e1005130.

11. Darwiche, R.; El Atab, O.; Baroni, R. M.; Teixeira, P. J. P. L.; Mondego, J. M. C.; Pereira, G. A. G.; Schneiter, R.; J. Biol. Chem. 2017, 292, 20558.

12. Scarpari, L. M.; Meinhardt, L. W.; Mazzafera, P.; Pomella, A. W. V.; Schiavinato, M. A.; Cascardo, J. C. M.; Pereira, G. A. G.; Int. J. Exp. Bot. 2005, 56, 865.

13. Evans, H. C.; Trans. Br. Mycol. Soc. 1980, 74, 515.

14. Calle, H.; Cook, A.; Fernando, S. Y.; Phytopathology 1982, 72, 1479.

15. Frias, G. A.; Purdy, L. H.; Schmidt, R. A.; Plant Dis. 1991, 75, 552.

16. Griffith, G. W.; Hedger, J. N.; Heredity 1994, 72, 278.

17. Wei, Y. D.; Shen, W. Y.; Dauk, M.; Wang, F.; Selvaraj, G.; Zou, J. T.; J. Biol. Chem. 2004, 279, 429.

18. Benchimol, R. L.; Viégas, I. J. M.; de Carvalho, J. G.; Rev. Cienc. Agrar. 2002, 37, 171. 
19. Barau, J.; Grandis, A.; Carvalho, V. M. A.; Teixeira, G. S.; Zaparoli, G. H. A.; do Rio, M. C. S.; Rincones, J.; Buckeridge, M. S.; Pereira, G. A. G.; Int. J. Exp. Bot. 2015, 66, 1325.

20. Gomes, D. S.; Lopes, M. A.; Menezes, S. P.; Ribeiro, L. F.; Dias, C. V.; Andrade, B. S.; de Jesus, R. M.; Pires, A. B. L.; Goes-Neto, A.; Micheli, F.; Fungal Genet. Biol. 2016, 86, 33.

21. de Souza Jr., J. O.; Marrocos, P. C. L.; Neves, J. C. L. In Cacau Cultivo, Pesquisa e Inovação, $1^{\text {st }}$ ed.; de Souza Jr., J. O., ed.; Editus: Ilhéus, Brazil, 2018, p. 305.

22. Nogueira, A. R. A.; Matos, A. O.; do Carmo, C. A. F. S.; Silva, D. J.; Monteiro, F. L.; de Souza, G. B.; Pitta, G. V. E.; Carlos, G. M.; de Oliveira, H.; Comastri Filho, J. A.; Miyazawa, M.; de Oliveira Neto, W. In Coleta, Acondicionamento e Preparo de Amostras, $1^{\text {st }}$ ed.; Nogueira, A. R. A.; Machado, P. L. O. A.; do Carmo, C. A. F. S.; Ferreira, J. R., eds.; EMBRAPA/CPPS: São Carlos, Brazil, 1998, p. 145.

23. Prado, R. M.; Nutrição de Plantas, $1^{\text {st }}$ ed.; Editora UNESP: São Paulo, Brazil, 2008.

24. dos Reis, P. S.; Estevam, I. H. S.; dos Santos, W. P. C.; Korn, M. G. A.; David, J. M.; David, J. P.; Araújo, R. G. O.; Pimentel, M. F.; Ferreira, S. L. C.; J. Braz. Chem. Soc. 2010, 21, 1905.

25. Anunciação, D. S.; Leao, D. J.; Jesus, R. M.; Ferreira, S. L. C.; Food Anal. Methods 2010, 4, 286.

26. Ribeiro, J. R.; Siqueira, S.; Novaes, C. G.; Santos Neto, J. H.; Quim. Nova 2016, 39, 442; Lima, G. F.; Ohara, M. O.; Clausen, D. N.; Nascimento, D. R.; Ribeiro, E. S.; Segatelli, M. G.; Bezerra, M. A.; Tarley, C. R. T.; Microchim. Acta 2012, 178, 61.

27. Statistica for Windows, version 13.3; TIBCO Software Inc., Palo Alto, USA, 2017.

28. Valle, R. R. M.; dos Santos, K. C. B.; da Silva, J. V. O. In Cacau Cultivo, Pesquisa e Inovação, $1^{\text {st }}$ ed.; de Souza Jr., J. O., ed.; Editus: Ilhéus, Brazil, 2018, p. 85.
29. Alloway, B. J.; Zinc in Soils and Crop Nutrition; International Zinc Association and International Fertilizer Industry Association: Brussels and Paris, 2008.

30. Reddy, A. S. N.; Plant Sci. J. 2001, 160, 381.

31. Epstein, E.; Bloom, A. J.; Nutrição Mineral de Plantas. Princípios e Perspectivas, $2^{\text {nd }}$ ed.; Editora Planta: Londrina, Brazil, 2006.

32. Souza, C. A. S.; Dias, L. A. S.; Aguilar, M. A. G.; Borém, A.; Cacau do Plantio à Colheita, $1^{\text {st }}$ ed.; Editora UFV: Viçosa, Brazil, 2016.

33. da Silva, I. L. S. S.; de Resende, M. L. V.; Ribeiro Jr., P. M.; Costa, J. C. B.; Camilo, F. R.; Baptista, J. C.; Salgado, S. M. L.; Cienc. Agrotec. 2008, 32, 61.

34. Chen, C.; Huang, D.; Liu, J.; Clean: Soil, Air, Water 2009, 37, 304.

35. Shahzad, B.; Tanveer, M.; Rehman, A.; Cheema, S. A.; Fahad, S.; Rehman, S.; Sharma, A.; Plant Physiol. Biochem. 2018, 132, 641.

36. Briat, J. F.; Dubos, C.; Gaymard, F.; Trends Plant Sci. 2015, $20,33$.

37. Souza, V. L.; Almeida, A. A. F.; Mangabeira, P. A. O.; Silva, D. C.; Jesus, R. M.; Valle, R. R.; Int. J. Phytorem. 2017, 19, 621.

38. Cambrai, A.; Marcic, C.; Morville, S.; Houer, P. S.; Bindler, F.; Marchioni, E.; J. Agric. Food Chem. 2010, 58, 1478.

39. Niether, W.; Smit, I.; Armengot, L.; Schneider, M.; Gerold, G.; Pawelzik, E.; J. Agric. Food Chem. 2017, 65, 10165.

40. Correia, P. R. M.; Ferreira, M. M. C.; Quim. Nova 2007, 30, 481.

41. Van Maarschalkerweerd, M.; Bro, R.; Egebo, M.; Husted, S.; J. Agric. Food Chem. 2013, 61, 1090.

Submitted: May 11, 2020

Published online: September 9, 2020 